\title{
Towards a Philosophy of Sustainability: The Gandhian Way
}

\author{
Archana Barua \\ Indiana Institute of Technology, India
}

Copyright (C) 2015 Horizon Research Publishing All rights reserved.

\begin{abstract}
The sheer proliferation of definitions of sustainable development is evidence of its contestability; for example, in Blueprint for a Green Economy, David Pearce, Anil Markandya and Edward Barbier (1989, pp.173-85) provide a 'gallery' of over 40 definitions."1For the scope of this article ,I will begin with the most widely used definition, taken from the Brundtland Report, that 'sustainable development is development that meets the needs of the present without compromising the ability of future generations to meet their own needs' (WCED, 1987).2While the concept of needs demands that 'overriding priority' should be given to the essential needs of the world's poor, both North and South, poverty and the unequal distribution of resources are identified as major causes of environmental degradation: 'Sustainable development requires meeting the basic needs of all and extending to all the opportunity to satisfy their aspirations for a better life' (WCED, 1987, p. 44). 3
\end{abstract}

Keywords Gandhian, Philosophy of Sustainability

\section{Introduction}

"The sheer proliferation of definitions of sustainable development is evidence of its contestability; for example, in Blueprint for a Green Economy, David Pearce, Anil Markandya and Edward Barbier (1989, pp.173-85) provide a 'gallery' of over 40 definitions." $F$ For the scope of this article ,I will begin with the most widely used definition, taken from the Brundtland Report, that 'sustainable development is development that meets the needs of the present without compromising the ability of future generations to meet their own needs' (WCED, 1987). ${ }^{2}$ While the concept of needs demands that 'overriding priority' should be given to the essential needs of the world's poor, both North and South, poverty and the unequal distribution of resources are identified as major causes of environmental degradation: 'Sustainable development requires meeting the basic needs of all and extending to all the opportunity to satisfy their aspirations for a better life' (WCED, 1987, p. 44). .3
Understanding sustainable development as a policy paradigm that could successfully shift the terms of debate from traditional environmentalism and its prime focus on environment protection, to the idea of sustainability that trades off social, economic and environmental priorities, development is now seen as a process of transformation that combines economic growth with broader social and cultural changes. In this background, this article makes an attempt at addressing some issues related to development at large , and to sustainable development in particular, with special emphasis on the Gandhian philosophical position on the need for safeguarding a moral and a humane dimension of development.

\section{Development, Sustainable Development, and a Divided World}

Against the backdrop of a divided world where with just over 6 billion people,some 1.1 billion have no access to drinking water ,2 billion have no electricity,2.4 billion live without proper sanitation, as many as 4 billion live without sound waste water disposal system, one can realize the deeper significance of one of Mahatma Gandhi's favourite aphorisms, that 'there is enough in this world for every man's need ,but not for every man's greed.' To quote Gandhi: 'Economics that hurt the moral wellbeing of an individual or a nation are immoral and sinful. Economic pursuits that commit one country to prey upon another are grossly immoral.' Gandhi is the first advocate of the thesis of sustainable development."Nature produces enough for our wants and if everyone took enough for himself and nothing more; there would be no pauperism and consumerism ",, which is to him another name for 'economic slavery '.

Advocating the thesis of sustainable development, Gandhi once posed the question 'how much a person can consume', or 'how much a person should consume', when our greeds are unlimited but nature's resources have a limit. Prior to Gandhi, Aristotle introduced the concept of welfare ethics in all areas including business and economy, since the very 'character of the economy is a life conductive and life 
serving one.' "This is a view inspired by Protagoras, according to which the purpose of the economy is to cater to authentic human needs, to enable humans to develop their full capabilities". ${ }^{5}$ In "Nichomachean Ethics" ,Aristotle highlighted material benefits that wealth can bestow on us as a means to an end : 'wealth is evidently not the good we are seeking; for it is merely useful and for the sake of something else'(Aristotle trans by Ross).

Wealth is conducive to something else, and this something else is there, because we can make a choice between what is desirable to us and what is not so desirable. Choice implies responsibility and it is a basic postulate of morality. Both Adam Smith and Karl Marx were concerned with human freedom, so are many modern day economists including the Nobel Laureate Amartya Sen. What this alternate model of development that accommodated sustainability into the growth model aimed at becomes relevant when we re-visit the growth model of developments and re-examine some of its contents and discontents.

The article makes use of phenomenological methodology in this regard that explores hidden layers of meaning in which social agents and actors are key participants in the construction of meaning in particular. Environment is always related to some specific perspectives and it can not aim at one homogeneous meaning that is applicable to one and all irrespective of situated differences of human agents in terms of culture, language or privileged or underprivileged positions in society. The article looks forward to a meaningful discourse on environment and sustainable development understanding meaning as a meaningful realm of dialogue and discourse. Working towards having new meanings phenomenological approach focuses on exploring how human beings experience the phenomenon, i.e. how they it; describe it; make sense of it. phenomenology is the exploration and description of phenomena, where phenomena are the things or experiences as human beings experience them. Phenomenology is a science of beginnings that demands a thorough, in-depth study of the phenomenon, which must be seen and described as clearly as possible. Accurate description is not a phenomenological end, however, but a means by which the phenomenologist locates the phenomenon's deeper, more generalizable patterns, structures, and meanings.H. Spiegelberg, The Phenomenological Movement, p. 2.

\section{Development as Growth and its Contents/Discounts}

Economic growth model of development also assessed development in terms of our purchasing and consuming capacities, and that way, Globalization became another profitable monopoly of a small group of privileged global elite .To quote Jean-Pierre Lehmann: "This perception is in fact quite accurate on two counts. First, it is the case that in the early $21^{\text {st }}$ century, some 20 percent of the world's population consumes 85 percent of the world's goods and services. Second, it is also the case that globalization has spawned a global elite who tend to be totally on the same page whether in Shanhai,Mumbai, Cape Town ,São Paulo ,Paris or Chicago ,but are seen as distant and aloof by their own more local compatriots. Goldman Sachs may be the epitome of what authors John Micklethwait and Adrian Woolridge in their excellent book "A Future Perfect : The Challenge and Hidden Promise of Globalization, " have referred to as the emerging "cosmocracy " : Goldman Sachs Man and Goldman Sachs woman are a universal species who speak the same language, dine in the same restaurants, drink the same wines, read the same papers, and are totally on the same cultural page, irrespective of their ethnic origins (Micklethwait and woolridge 20000).Even among the well-to-do ,therefore ,there is growing cleavage between those who see the great potential gains of globalization (the Goldman Sachs tribe) and those who see their privileges and positions eroding or who live in despair of ever improving their lot.(Guha 2006)" 6

John Kenneth Galbraith in his the Affluent Society, termed 1950's America ,the "affluent society "so dedicated to affluence that the possession and consumption of material goods was its exclusive standard of individual and collective achievement. " ${ }^{7}$ Galbraith quotes Anthropologist Geoffrey Gorcer's remarks that in modern America "any device or regulation which interfered, or can be conceived as interfering, with [the] supply of more and better things is resisted with unreasoning horror, as the religious resist blasphemy ,or the warlike pacifism" (Guha 2006). ${ }^{8}$

While speaking to his fellow Americans that "we have not yet learned the difference between yield and loot. We do not like to be economic realists., "9 Berkeley geographer Carl Sauer ,shares Gandhian concern for an a-moral and, what Gandhiji would condemn as the satanic mode of development, 'when happiness of the one is defined in terms of the suffering of the other'.

Table 1. The USA's share of World consumption of Key Materials (figures in million tons )

\begin{tabular}{|c|c|c|c|}
\hline $\begin{array}{c}(1) \\
\text { Material }\end{array}$ & $\begin{array}{c}(2) \\
\text { World } \\
\text { Production }\end{array}$ & $\begin{array}{c}(3) \\
\text { US consumption }\end{array}$ & $\begin{array}{c}(4)^{*} \\
3 \text { as \% of } 2\end{array}$ \\
\hline Minerals & 7,641 & 2,410 & 31.54 \\
Wood Products & 724 & 170 & 23.48 \\
Metals & 1,196 & 132 & 11.03 \\
Synthetics & 252 & 131 & 51.98 \\
All materials & 9,813 & 2.843 & 28.97 \\
\hline
\end{tabular}

*The USA's population is approximately 4.42 percent of total world population. Souce : Computed from State of the world 1999 ( New York: Worldwatch Institute and W.W.Norton,1999): ( Guha 2006, p.225).

\section{The Environment in Question: Who is to be Blamed?}

There are two ways of looking at environmental concerns. For the poor, it is they who are now bearing the burden of a rapid growth model and the consumerist pattern of the developed Nations. Since the Commonly used indicators for progress, the measurement of GDP Index of development do 
not take the depletion of natural resources or the pollution of the nature and environment into account, the external cost of resource use and pollution are not being internalized. As a result, society as a whole is carrying the burden as well as the costsass with that burden. To make things worse, the burden is shared unequally across the globe: people in poor country often carrying large share of the burden than those in richer countries. A good example is the impact of climate change, which in the form of droughts and extreme weather events is already affecting developing nations to a much greater extent than developed countries, although much of the problem is being caused by consumption and lifestyle patterns in industrialized Nations. Simultaneously, poorer developing Nations often lack the means to adapt to climate changes. On top of it economic development and the creation and accumulation of wealth model still rely on the exploitation of natural resources.

The air pollution from factories is caused as toxic fumes are emitted into air. In 1984 Bhupal disaster released toxic gas from an American owned chemical plant killing more than 2000 people and it left more than 2 lakhs injured. In 1965 the lead concentration in the Greenland ice was 400 times higher than the level in 800 B.C. Besides, Acid rains , depletion of Ozone layer ,the Green house effect, water pollution, land pollution, deforestation ,pesticide pollution, noise, nuclear and ocean pollution are also associated with man caused disasters along with many others of its kind.

It is recorded that almost 625 billion dollars would be needed annually for the action plan to control pollution. United States spends 50 billion dollar per year for pollution control which would be 2 percent of the G.N.P. It is obvious that only the strongest economics will be able to maintain the level of domestic environmental protection and protect their domestic industry despite the fact that they are not the real culprits of this crime. "The north gains cheap access to cheap raw materials and hinders access to markets for processed products from those countries ; it imposes a system of world trade organization that favors the strong ;it makes use of large areas of land in the south ,tolerating soil degradation, damage to regional eco systems, and disruption of local self-reliance ;it exports toxic waste; it claims patent rights to utilization of biodiversity in tropical regions etc. " 10 " The economically weak South is besieged by GATT which, encourages shifting of factors of production from food crops to environmentally less friendly cash crops for export ,discourages restrictions on food export even in times of domestic food shortages and is silent on permitting countries to protect themselves against 'eco dumping.",11 The struggles against environmental injustice are growing, and the name EJ is now used more frequently outside the USA. Thus, in Mozambique there is a very active group with the name of Justiça Ambiental (a member of Friends of the Earth International). In Brazil there has been a Network of Environmental Justice since 2001,formed by EJOs, unions, indigenous groups and university researchers.

Over the years, the US Environmental Justice movement helped reframe environmental concerns from an environmental justice perspective that seeks to redefine environment as a safe place to live, work, learn, as a safe place to live, work, learn with special focus on deprived ones and the marginal communities and their vulnerability. The environmental justice movement has demonstrated that pollution's effects often fall disproportionately on the health and communities of people of color, low-income populations, and Indigenous populations. It is thus not surprising that the causes and effects of global climate change are also unequally distributed that needs to be addressed urgently and also with humanitarian as well as moral concern, an area that is sought to be addressed in this article with its emphasis on Gandhian approach to sustainability and development .

\section{Environment Politics and the Conflict of Interests}

It is said that :'Sustainable development, like beauty, is in the eye of the beholder; it therefore promises something for everyone'. Economist Lester Thurow believes that environment movement is being supported mainly by upper middle class people who have gained economic security and now want to improve the quality of their lives further by reducing environmental pollutants. Environment protection in the North came to be viewed as a part of the great growth model of development when nature too was seen as one of the precious goods that satisfies man's taste for a altogether different quality of life which also satisfies man's urge for 'a sense of beauty and solitude', 'a sense of the sacred', as well. The popular support for the protection of wilderness in the North reflected this taste for solitude at the heart of a machine world. This taste is also the gift of technology and development to some extent as the virgin wild nature is also made accessible to human admirers only because the car opened up the wild to all. "Thus in a curious paradox, the car "the most modern creation of industry ", becomes the vehicle of anti-industrial impulses, taking one to distant adventures, to " homely little towns, enchanting fairytale forests, far from stale routine, functional ugliness or the dictates of the clock. " 12

For others, exploding numbers seem at fault with environment degradation, countries such as India and specially Bangladesh were commonly blamed. In his book The population Bomb Paul Ehrlich, describes his emotional experience of population explosion when he had this particular experience in one stinking night in Delhi a couple of years ago :" As we crawled through the city, we entered a crowded slum area. The streets seemed alive with people. People eating, people washing, people sleeping. People visiting, people arguing and screaming. People thrusting their hands through the taxi window, begging .People defecating and urinating .People clinging to buses .People herding animals. People, people, people." 13

Not surprisingly the activists of these countries were quick to take offence blaming the consumer pattern of the developed Nations like the USA which is notorious for 
consuming a far greater proportion of the world's resources. It was observed that the real population problem is in America where the birth of one child has the same impact on the global environment as the birth of, say, 70 indian children .Guha finally comments:" A Bangladsehi made this case whenever he could, in the United Nations and elsewhere. But after a visit to an American supermarket, he was obliged to modify his argument, claiming instead that the birth of an American dog or cat was the equivalent, ecologically speaking ,of the birth of a dozen Bangladeshi children." 14

Guha comments : "My view is that the clearest connection between democracy at home and imperialism abroad is provided by the American consumer economy, its apparently insatiable greed for resources of other lands .Contrary to what Wenell Berry thought, wilderness at home continued to be protected only because the ecological footprint of the American consumer grew, grew and grew .The freebooting instincts of the pioneer, which were once set loose on the lands of the wild west that were formally part of the nation ,now found play in lands and waters East, South ,and North regardless of whether these belonged to America. To cite only the most obvious example, the USA imports well over $50 \mathrm{pc}$ of the oil it consumes." 15

In between these two ways of looking at who is to be blamed for environment disaster, the 'Brundtland Report ' on our common future, reflects a shift in thinking about the environmental issues including sustainability. It sought to accommodate both sustainability and development by bringing environmental concerns of the developing and the developed under one common banner. Although closer in spirit, in the Gandhian model of sustainable development, the village remains the unit of production and distribution. Advocating 'simple living and high thinking', Gandhi prioritizes the cultural and the spiritual life style, usually associated with village and peasantry, in which the small is the beautiful. Others like J.C. Kumarappa soon followed Gandhi to show support and solidarity in this village-centric and predominantly agrarian and deeply humanistic economic model of sustainable development. Describing him as the "single most important influence on the environmental movement",Ramchandra Guha says that it was left to J. C. Kumarappa and Mira Behn to build an ecological programme along Gandhian lines with exclusive focus on environmental problems of the rural areas.

Gandhi's voice of environmentalism was not the lone voice at the turn of the twentieth century. Rabindranath Tagore represented nature in his poems and works. Shantiniketan, the institution that he founded, was another example of nature-friendly study and living. While he did not emphasize the notion of self-sufficient village republics, Tagore questioned the value of state power and, in fact, of nationhood itself for the life of a people. "He shared with other Bengali thinkers of the nineteenth century the notion that society rather than the state was the central focus of Indian life. Like Gandhi, he too was extremely suspicious of centralized state power. Only, he went further to reject the need for nationhood which raised barriers between man and man and led to vicious conflict. The fact that the idea was alien to India was for him a plus point. His agenda for national reconstruction, like Gandhi's, emphasized the rural unit rather than the grand edifice of the state. ${ }^{16}$

On the whole, the Gandhian model of sarvodaya has built in mechanism for 'growth of justice' and minimization of wants as against the giant multinational corporations'(MNC) setting guidelines for maximization of wants that keep alluring people to a life of mass consuming and a consumerist way of life.

\section{The Gandhian Way to Sustainable Development and its Beyond}

Environment and sustainability remained debatable issues especially from the Third World perspective as well. Greatly inspired by Gandhian philosophy of deeper interrelationship between man, nature and environment, different forms of environmental movements, cropped up. Drawing heavily on the teachings of Gandhi, inventor of the concept of deep ecology Arne Næss, along with others like E F Schumacher, shared common ideas with Gandhi that science and technology has its limitations and intuition is a source of knowledge that provides the missing gap. Deep ecological elements are prevalent in Gandhi's environmental philosophy as well. Gandhi, believed that nature could exist without humans, a prospect that fascinated and frightened him, which eventually prompted him to focus on the relation between human beings and the environment. "I need no inspiration other than Nature's. She has never failed me as yet. She mystifies me, bewilders me, sends me to ecstasies." 17

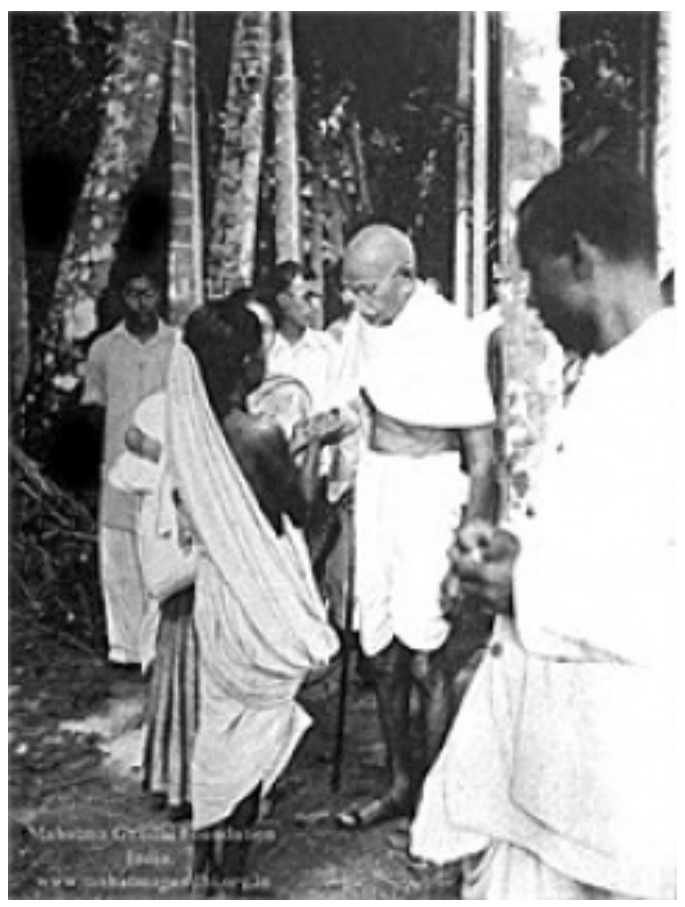

The Gandhian Way : 'balancing between needs and greed' 
However Gandhian position on environmentalism is more akin to human centric shallow ecology than bio centric deep ecology. The basic difference between deep and shallow ecology is that the latter takes an anthropocentric (human-centred) view of the world, whereas deep ecology is eco-centric, placing equal value on non-human organisms and, indeed, physical features. If we go by the ideas generated by the environmental movement in India, which is strongly influenced by Gandhi, these are also human welfare centric besides accommodating larger interest of all life into its fold. The strength of human ecology, and also of Gandhian philosophy, lies in its ability to see human beings and their environment as mutually interlinked, as part of an integrated whole.

Unlike in the West, almost all the Indian environmental movements also paved way for sustainable development in a Gandhian way. These reflected worries and apprehensions of the ecosystem people who share natural and spiritual bond with nature, and for these tribes, fisher folk, other underprivileged section of the society, forest preservation or river preservation became synonymous with a movement for safeguarding their own local, ethnic and marginal identity that faces threat of extinction along with the forest,river , and the mother earth, who sustains them all. Following the footsteps of Mahatma Gandhi, leaders like J.C. Kumarappa, contemporary Gandhian environmentalists like, Baba Amte, Medha Patkar and Sundarlal Bahuguna among others ,could see cities as corrupting and polluting, both morally as well as ecologically. In its extreme form this may lead to some kind of demarcation between the two: cities versus villages, sustainability versus development, and so on. Staunchly Gandhian in its ideology, the Narmada Bachao Andolan, is committed to holding on non-violence even in the face of extreme provocation. Among its prominent leaders, Gandhian reformers like Baba Amte, Medha Patkar, and others creatively sought out ways to breakdown and reconnect the local/global. Set up in 1986 under the leadership of Medha Patkar, NBA emerged as a social movement consisting of tribal people, Adivasis, farmers, environmentalists and human rights activists against the Sardar Sarovar Dam being built across the Narmada river, Gujrat, India . Critiquing the social and environmental impact of large development projects specially on the life of the tribals, and looking toward a new environmentally sustainable water policy, it also raises issues related to human rights and justice, alternative development policies, environmental issues related to big dams in general and the Narmada project in particular. "A fundamental question that the NBA has raised has been about the financial costs incurred by the State on huge development projects such as the SSP and the social costs incurred by ordinary people for the sake of a privileged few. Inherent in these questions have been the role of the state as it unequivocally alters the lives and livelihoods of lakhs of people through its persistent and seemingly blind facilitation of this unequal cost-benefit balance. ${ }^{, 18}$ Some others of environmental movements of its kind namely like the Krihsnk Mukti Sangram, led by Akhil
Gogoi in Assam, are protests against big dams that will cause harm to ecosystem, local people and their river related trades and the folk culture and their sense of identity. Nature and environment are thus seen as social and cultural constructs.

Contemporary environmental writers such as Vandana Shiva, Anil Agarwal, Madhav Gadgil and Ramachandra Guha, among others, have acknowledged their debt to Gandhi's ideas. Gandhi drew on a number of Western thinkers from John Ruskin to Henry David Thoreau, to name a few, who, although were not against the modernist project, romantically cherished the pre-industrial order. All these shades and layers of his deeper self-realization have inspired different kinds of Environmental Movements particularly in India.

Inspired by Gandhian ideals, the founder of the Chipco movement Chandi Prasad Bhatt, was of the rare progressive minds. He claimed that their movement was not against science and technology as such, but against misuse of science when nature is used for profit motive alone. Born in the Alakananda valley, the Chipco movement with its main aim of fostering of love for trees in the hearts of humans, later moved eastward to Kumaon to protest against commercial forestry. In the late Seventies the adivasis protested vigorously against the conversion of their sal forests to teak plantations, a scheme intended to benefit urban consumers, timber merchants and the forest department. Its pet slogan "sal for Jharkhand ", sagwan for bihar' "showed its concern for felling down sal trees shorea robusta, which is of highly prized firewood for local community and replacing it with teak wood plantation for the benefit of commercial purpose. The protesters who uprooted the teak saplings suggested that sal means Jharkhand, sagwan (teak) means Bihar. It was a symbolic move against deforestation. It asked for re-cosonstruction than de-construction,for preservation and for a cautious and sustainable use of the forest and of nature .

Preventing a group of labourers, who were sent by a distant Dehradun based contractor to fell down Sal trees from the forest as these tress were auctioned off to him, the leader of the Himachal Mahila Mandal Gaura Devi ,along with other female members of the panchayat, rushed to meet them and to plead them not to fell down trees. This is how this simple housewife and village woman explained to them why they care for the forest and for the trees and why everyone else should develop love for trees: "Brothers, these forests are like our maternal home [maika]..We get herbs, fuel, fruits and vegetables from them. Cutting the forests will result in floods. Our field will be washed away. Please have your food and come with us to our village. When our men come back we will collectively take a decision'. ${ }^{18}$

The Chipco movement shows an way to environment protection : "these forests are like our maternal home [maika]"

In his documentation of the socio-cultural uniqueness of Indian conservation movements, Ramchandra Guha pays glowing tribute to these moral and spiritual Gandhian leaders 
like Gaura Devi, Medha Patkar, who take on a dishonest bureaucracy and swear by the community's commitment to nature .Guha pays tribute to the "subaltern social ecology" of Chandi Prasad Bhatt, another Chipko pioneer, and the scholarly Madhav Gadgil, for his democratizing influence on environmental thought and biodiversity conservation. All these leaders followed the footsteps of Gandhi in some form or other.

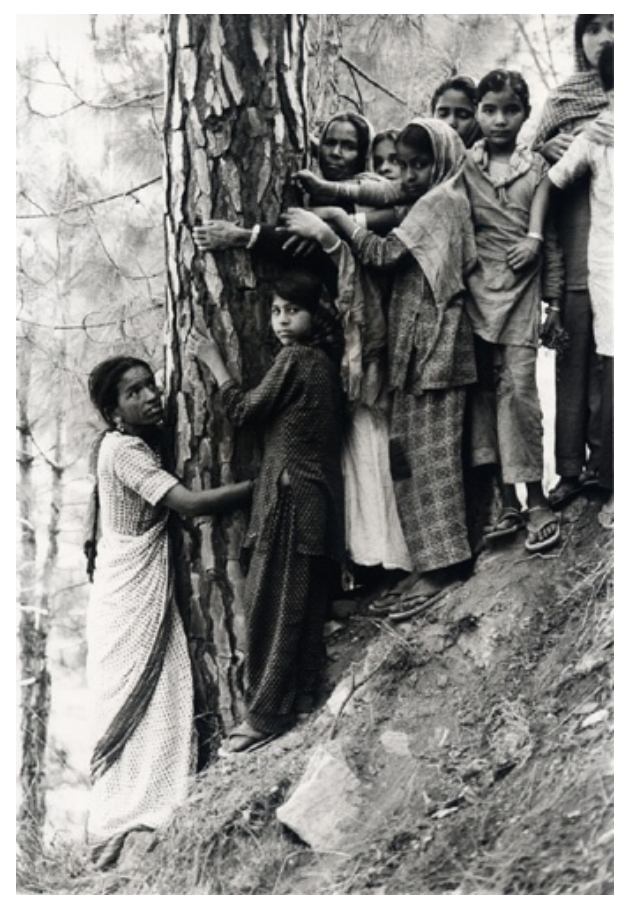

\section{Growth, Development and Sustainable Development : The Gandhian Way and Beyond}

Deeply Committed to a spiritual and a moral philosophy of life , Gandhi pays homage to the age old traditions that keep room for harmonious growth of one and all. Its basic motto is 'live and let others live.' With more emphasis on 'tyaga' than on 'bhoga', Gandhi advocates a philosophy of 'bhoga' with a sense of 'tyaga'.One has to live a life with minimizing one's needs and in the Gandhian scheme peasant and the simple virtues of the village and peasantry are prioritized. Gandhi would have preferred if the peasant wants to remain a peasant. It was more in line with his philosophy of prioritizing the spiritual and moral dimension of life than the wealth centric and profit oriented industrialization and corporate lifestyle. For Gandhi, industrialization and profit generation were at odds with moral progress. He said: "The incessant search for material comforts and their multiplication is an evil. I make bold to say that the Europeans will have to remodel their outlook, if they are not to perish under the weight of the comforts to which they are becoming slaves." Further, with a prophetic vision, Gandhi warned: "A time is coming when those who are in mad rush today of multiplying their wants, will retrace their steps and say; what have we done?" 19

If we go by the contemporary trends for the ecosystem people, here the role model is that of an ideal ambivalent who can aspire to buy anything, including pollution less air and water. The majority will welcome the statement that ,' Growth has no set limit in terms of population or resource use beyond which lies ecological disaster' (WCED, 1987, p. 45)." Indeed, Brundtland demands a revival of growth in developing countries to help alleviate poverty and provide for basic needs, although it seeks a more 'eco-friendly' type of growth that is 'less material- and energy-intensive and more equitable in its impact' (WCED, 1987, p. 52). ${ }^{\text {"20 }}$ It is obvious that less developed countries will want to become developed ,and unlike Gandhi, and a handful of Gandhians, majority will follow a path of comfort ,luxury and better opportunities in life. Ramachandra Guha tries to show the trends of consumer choice in terms of simple hierarchies of fuel, housing, and transportation(Guha 2006 ,p.244): Hierarchies of Resource Consumption

\begin{tabular}{|c|c|c|}
\hline Fuel used & Mode of housing & Mode of transport \\
\hline Grass & Cave & Feet \\
Wood, Dung & Thatched hut & Bullock cart \\
Coal,Kerosine & Wooden house & Bicycle \\
Gas & Stone house & Motor scooter \\
Electricity & Cement house & Car \\
\hline
\end{tabular}

"To go down any of these lists is to move toward a more efficient and generally a safer mode of consumption. Why would one abjure cheap and safe cooking fuel, for example, or quick and reliable transport, or stable houses that can outlive the monsoon?", Guha wonders. "To prefer gas to dung for your stove, a car to a bullock-cart for your mobility, and a wood home to a straw hut for your family is to move toward greater comfort, well-being and freedom. These are choices that, despite specious talk of cultural difference, are desired by all and ought to be made available to all. " 21

Ramchandra Guha comments: "In 2002 the demand for cars in China `increased by 56 pc , in 2003 by 75 pc. In 2004 the Chinese state news agency Xinhua proclaimed that "China has begun to enter the age of mass car consumption .This is great historic advance ." 22

\section{Conclusions}

Even if we go beyond Gandhi, how far we can go? Again and again the familiar Gandhian voice intervenes and keeps posing new challenges before us. When we are optimist of meeting all our needs by the road of development, Gandhi quietly reminds us : "It took Britain half the resources of the planet to achieve this prosperity. How many planets will a country like India require!"23

Ramachandra Guha asks this typical Gandhian question: "Can the world as a whole achieve American levels of car ownership? "24 Guha continues: "A question never asked by ecologists, or by the economist, is this -can the world as a 
whole achieve American levels of car ownership ? Can there be a world with 4 billion cars, a china with 700 million cars, an India with 600 million cars? Where will the oil and gas to run them come from ? I take the car here as merely indexical of a certain style of consumption. For with its use also come demands for other resources, for other goods .In China and India now, as in Africa of the 1950s, with the wish to possess more elegant cars has come the desire for more exotic food, more erotic clothing ,more elaborate entertainment." 25

Gandhi remains the first and foremost advocate of the thesis of sustainable development for all times to come. Introducing the humane dimension of sustainable development, Nobel Laureate Amartya Sen ,seeks to restore the much forgotten dimension of human dignity into the scope of development by his innovative idea of 'development as freedom'. Development is valued not only in terms of economic growth and high income or high consumption rate but it depends on the extent to which people have the opportunity to achieve outcomes they value. Some non-income variables that persons value are such important matters as the freedom to live long ,to live in peaceful and crime free communities etc value most are not linked with economic prosperity. Thus, both the process aspect and the opportunity aspect of freedom require us to go well beyond the traditional view of development in terms of "the growth of output perhead." 26

Gandhian concern for minimizing wants and reducing greed is also reflected in some recent innovative measures taken by advocates of green development, welfare development, sustainable development etc. A retreat of the rich from over consumption is thus a necessary first step toward allowing space for improvement of the lives of an increasing number of people. Spanish economist Juan Martinez -alier suggests an way out :"In the poor countries of Asia and Africa, firewood and animal dung are often the only source of cooking fuel. These are inefficient and polluting , and their collection involves much drudgery. The provision of oil or LPG to the cooking stoves of the Niagerian or Nepali peasant woman would greatly improve the quality of their lifves. This could be very easily done, says Martinez -alier ,if one very moderately taxed the rich...". He continues :"The solution is simple-namely ,that oil consumption in the rich countries should be taxed, while the use of LPG or kerosene for fuel in poor countries be subsidized . ${ }^{27}$ This would allow the poor to ascend one small step up the hierarchies of resource consumption with a very little sacrifice from the rich.

Recently among the developed nations Germany is showing real interest in reorienting economy and society to a more sustainable path by extended treatment of overconsumption. The targets set by the Wüppertal Institute for a "Sustainable Germany" and for retreat of the rich from overconsumption, includes strategies including " elimination of subsidies to chemical farming, the levying of ecological taxes (on gasoline, for example), and the move toward slower and fuel efficient cars while shifting the movement of goods from road to rail." ${ }^{28}$ The following table is an illustration of some such policies adopted of late :

Mixing moral ends with material means

\begin{tabular}{|c|c|}
\hline Environmental Indicator & Target set for the year 2010 \\
\hline \multicolumn{2}{|c|}{ Energy } \\
\hline Energy consumption (overall ) & at least $-30 \%$ \\
\hline Fossil fuels & $-25 \%$ \\
\hline Nuclear power & $-100 \%$ \\
\hline Renewables & +3 to $5 \%$ per year \\
\hline Energy efficiency & +3 to $5 \%$ per year \\
\hline \multicolumn{2}{|c|}{ Materials } \\
\hline Non -renewable raw materials & -25 \\
\hline Material productivity & +4 to $6 \%$ per year \\
\hline \multicolumn{2}{|l|}{ Substance released } \\
\hline Carbon dioxide & $-35 \%$ \\
\hline Sulphur dioxide & -80 to $90 \%$ \\
\hline Nitrogen oxides & $-80 \%$ by 2005 \\
\hline Ammonia & -80 to $90 \%$ \\
\hline Volatile organic compounds & $-80 \%$ by 2005 \\
\hline Synthetic nitrogen fertilizers & $-100 \%$ \\
\hline Agricultural biocides & $-100 \%$ \\
\hline Soil erosion & -80 to $90 \%$ \\
\hline \multicolumn{2}{|c|}{$\begin{array}{l}\text { Agriculture } \quad \text { extensive conversion to organic farming methods } \\
\text { Forestry }\end{array}$} \\
\hline
\end{tabular}

*Source: Sachs,Loske and Linz, et al., Greening the North : ( Cited in Guha 2006 ,p.247)

Gandhi's crusade was not against growth and development, nor against science and technology as such. It was a crusade against the misuse of science and technology that leads to unsustainable and inhumane and unfair mode of development. If development wears a humane face and is welfare-centric, this is the way Gandhi would have liked it to proceed .This would be a new avtar of Gandhian brand of sustainable development in some form. From a Gandhian perspective, the present environmental mess, ranging from deforestation, soil and biodiversity loss, to pollution and climate change, is not a disease but only a symptom. A good doctor treats the disease and not the symptom. The disease is the very concept and patterns of growth and development that are being followed everywhere. If the perspective changes the disease is diagonosed by a good doctor.

"In conclusion, we can say that Gandhi's environmentalism fitted in with his overall vision for India and the world that sought to extract from nature what is absolutely necessary for human sustenance. His ideas on environment are intimately linked with all his ideas relating to the polity, economy, health and development. His asceticism and simple living, a rural- centered civilization based on village autonomy and self-reliance, handicrafts and craft- centered education with emphasis on manual labor , and absence of exploitative relationships, are infused with elements of an ecological vision (Jones 2000). Even his approach to gender he did not attempt to break the connection with nature. "29

Louis Fischer has rightly asserted :"If man is to survive and flower in freedom, truth and decency, the reminder of the 20th century and what lies beyond must belong not to Lenin 
or Trotosky, not to Marx or Mao, or Ho or Che ,but to Mahatma Gnadhi”. 30

\section{REFERENCES}

[1] David Pearce, Anil Markandya and Edward Barbier (1989, pp.173-85). Blueprint for a Green Economy,(London: Earthscan Publications Ltd., 1989), pp.173-85.

[2] WCED( 1987). Our Common Future (First ed.).(Oxford : Oxford University Press), p.44

[3] ibid. p. 44

[4] Mohandas Karamchand Gandhi; Ministry of Information and Broadcasting Government of India. Publications Division(.1958-1982.).The Colected Works of Mahatma Gandhi (Dehli : The Publications Division, Ministry of Information and Broadcasting Government of India).

[5] Pirson, Michael [ET AL], (2009).“'Introduction : humanism in business " ,in HUMANISM IN BUSINESS / EDITED BY HEIKO SPITZECK ... [ET AL.]. (Cambridge : Cambridge University Press), P...3-

[6] Lehmann , Jean-Pierre (2009).”Globalization and the power of individuals" ,in HUMANISM IN BUSINESS / EDITED BY HEIKO SPITZECK ... [ET AL.]. (Cambridge : Cambridge University Press). ,p 349

[7] Galbraith , John Kenneth(1958). The Affluent society (Boston :Houghton Mifflin ). p.221

[8] .ibid.

[9] Sauer, Carl (1938)."Theme of Plant and Animal Destruction in Economic History" , in idem, Land and Life (Berkeley: University of California Press, 1963). (Quoted in Guha,Ramachandra p.222.)

[10] Wolfgang Sachs et al.,(1998). Greening the North: A Post-Industrial Blueprint for Ecology and Equity (London: Zed Books).

[11] Aditi kapoor (994) : The Times of India ,Patna ,10th august

[12] Sachs ,Wolfgang, (.1992) For Love of the Automobile : Looking back into the History of our desires (Berkeley : University of California Press ),pp.150-1

[13] Ehrlich,Paul(1969), The Population Bomb (New York:Ballantine books ),p.15

[14] Satyajit Singh, (1994)." Environment, class and State in India:A Per on Sustainable Irrigatio ,unpublished phd dissertation ,dept of political science, DU. ( quoted in Guha, Ramachandra (2006). How Much Should A Person Consume?( Permanent Black :The University of California Press,Berkeley), p .225.

[15] Guha, Ramachandra (2006). How Much Should A Person Consume?( Permanent Black :The University of California
Press,Berkeley),,p.227

[16] Tagore, Rabindranath (1975: 2nd edition, 3rd reprint )." Atmashakti" (Strength of One's Own), in Rabindra-rachnabali, vol. 3 (Viswa-bharati, Calcutta,),pp. 555

[17] Quoted in Moolakkattu, John S., "Gandhi as a Human Ecologist ", in Journal of Human Ecology, 29 (3) :151-158 (2010) .online :www.krepublishers.com/.../JHE-29-3-151-10 -2065-Moolakkattu-J-S.(accessed July 2010)

[18] Gaura Devi : Ek Ma Ki Yad in Uttara mahila Pattrika ,vol 2 ,no.1., 1991, supplemented by interviews with chandi Prasad bhatt ,gopeswar ,june 1982, (quoted in Guha, Ramachandra (2006). How Much Should A Person Consume ?( Permanent Black :The University of California Press,Berkeley)., pp. 60-61.

[19] Quoted in Moolakkattu, John S., "Gandhi as a Human Ecologist ", in Journal of Human Ecology, 29 (3) :151-158 (2010) .online www.krepublishers.com/.../JHE-29-3-151-102065-Moolakkattu-J-S. .(accessed July 2010)

[20] WCED( 1987). Our Common Future (First ed.).Oxford : Oxford University Press.pp. 52-53.

[21] Guha, Ramachandra (2006). How Much Should A Person Consume ?( Permanent Black :The University of California Press,Berkeley),p.247.

[22] " Special report :Cars in China “,in The Economist ,June 4 2005(Quoted in Guha, Ramachandra (2006). How Much Should A Person Consume?( Permanent Black :The University of California Press,Berkeley).

[23] Collected Works of Mahatma Gandhi (CWMG) 1967.New Delhi: Publications Division, Government of India.

[24] Guha ,Ramachandra(2006). How Much Should A Person Consume ? (Permanent Black :The University of California Press,Berkeley),pp.237

[25] Guha, Ramachandra (2006). How Much Should A Person Consume ?( Permanent Black :The University of California Press,Berkeley).,p 237.

[26] Sen,Amartya (2009). ("Development as freedom :individual freedom as a social commitment ",in HUMANISM IN BUSINESS / EDITED BY HEIKO SPITZECK ... [ET AL.]. (Cambridge : Cambridge University Press).,pp. 156-175.

[27] Juan Martinez -alier, (1977)."Poverty and the Environment ",in Ramachandra Guha and Juan Martinez -alier, Varieties of Environmentalism:Esseys North and South(London:Earth scan ).

[28] Quoted in Guha, Ramachandra (2006). How Much Should A Person Consume ?( Permanent Black :The Univ of California Press,Berkeley ).pp.248-49.

[29] Quoted in Moolakkattu, John S., "Gandhi as a Human Ecologist ", in Journal of Human Ecology, 29 (3) :151-158 (2010) .online www.krepublishers.com/.../JHE-29-3-151-102065-Moolakkattu-J-S. 9(accessed July 2010).

[30] Fischer, Louis. Gandhi: His Life and Message to the World. New York: Penguin, 1982. 